\title{
Research on the Necessity and Approaches of College Counselors Professional Development
}

\author{
Huang Lin \\ Tianfu College \\ Southwestern University of Finance and Economics \\ Mianyang, Sichuan, 621000, China
}

\begin{abstract}
The college counselors are the backbone of student work and the organizers, perpetrators and mentors of ideological and political education and management, therefore, their professional development is important for the comprehensive development of the school. According to the author many years of study and practical experience, this paper analyzes the connotation of college counselors professional development, and discusses the necessity of professional development, and finally puts forward specific countermeasures for college counselors professional development. The research results will have a certain reference value for the university teachers and schools to enhance their quality of teacher skill.
\end{abstract}

Keywords- College counselors; Professionalization; Necessity; Approaches

\section{INTRODUCTION}

With the change of the background and educational environment, the traditional concept of education, experience, management has been unable to adapt to the new situation, urgently to improve and innovate, which also presents new challenges and tests for the college counselors, and how to build a professional, career-oriented counselors has important implications for personnel training.

\section{THE CONNOTATIONS OF COUNSELOR TEAM PROFESSIONAL DEVELOPMENT}

Social labor division theory is the theoretical basis professionalism, and the premise of social labor division is the emergence of environmental groups. Generation and career development is an objective reflection of social development and progress of human civilization. Professionalism means social activity patterns reflected from community by the people, and it is a particular kind of job status, including literacy, behavior norms and skills. Counselor professionalism means college counselors work become a specialized profession, with its own irreplaceable job requirements and occupational characteristics, and there is a corresponding professional training institutions and professional standards in security systems, and also has a corresponding social status and economic status, including the construction of professionalism team, setting professionalism jobs and training professionalism spirit. The real demands of the counselors professionalism is to take counselors as professional teachers engaged in ideological and political education and student affairs administration of the profession, rather than the political cadres out of the teaching profession. Therefore, it needs to build counselor team just like treating professional teachers.

\section{THE ANALYSIS OF THE NECESSITY OF PROFESSIONAL COUNSELORS DEVELOPMENT}

\section{A. Professional development is the objective requirements of the ideological and political education development}

Counselor is the main body and backbone of college students' ideological and political education and student affairs administration, and their roles and responsibilities of the position depends fundamentally on the fundamental requirements of socialist construction to train qualified builders and reliable successors. For over 60 years from new China was founded, ideological and political education is characterized by the revolutionary shift to construction features, from taking class struggle as the key link to taking economic construction as the center, from a planned economy to adapt to the socialist market economic system to adapt to the "trinity" to adapt to the "four bit one" which highlights the ideological and political the overall national situation of education services to the fundamental demands. Counselors are part of the ideological and political education workers, what stage they are in, what kind of role they play, what kind of responsibility they bear, obviously needs to change with the overall ideological and political education according to the requirements. In the new historical period, ideological and political education of college students is facing unprecedented challenges and opportunities, counselors must adapt to higher education from elite education to mass education changes.

\section{B. Professional development is the inherent demands of ideological and political education rules}

The object of ideological and political education is the people, so ideological and political education is the man's work, that is, through the ideological and political education work undertaken to solve the problem of people's thinking and understanding, mobilize the enthusiasm of people to cultivate innovation, thus maximizing the value of its own, and ultimately promote the guarantor round development. Fundamentally, the main job of counselor is ideological and political education of students to guide students' development. Its simplicity and transactional work is 
superficial, and the true value is knowledge and creativity, which determines the counselors work must have the appropriate rules, including theory and practice to solve ideological problems with solving practical problems combined. Meanwhile, the rules grasping needs to practice to gain experience, but the system needs to support the business requires not only a bold counselors work in practice emancipating, seeking truth from facts, but also to continue to strengthen the growth characteristics of college students development of appeal accept methods of scientific research, and this is also inseparable from the professional development.

\section{Professional Development is counselor' subjective career craving}

Counselors' differences identity and fuzzy positioning in different universities makes job responsibilities counselor not scientific definition, and many counselors have to do anything, nothing major, major effort on the transactional work, no too much time and energy to engage in academic research, in identity management, due to the limitations of the object and scope of work, the right to speak or executive power is often overwhelmed by the academic discourse, focusing transactional work and professional promotion, lack of professional recognition and mobility difficulties and other conflicts. Objective reality inevitably produces subjective aspirations, in the universities environment, because of academic, professional and other aspects of in a relatively weak, relative to a single personal development, leading them to engage in long-term heavy work and subjective demands that are not met, which prompts them to pay more attention to realize their own values, especially the students care about social acceptance and recognition often makes them not satisfy with the completion of general trivial passive student affairs, but rather try to pursue the perfect result. Therefore, they are more interested in creative work to solve a problem, meet the growing needs of the students which is taken as a kind of fun, a way to reflect self-worth. In the development path selection, the professionalism is undoubtedly the best choice for them to meet the subjective desire, and they hope through professionalism development to make their work more in the field of independent and originality, and the pursuit and in the process from the work itself to meet and development, and pursuing to meet and develop from the work itself' in this process.

\section{THE APPROACHES FOR PROFESSIONAL COUNSELORS DEVELOPMENT}

\section{A. Give counselors teachers professional identity and peer policy treatment}

As a carrier of knowledge resources, counselors no longer as workers who are everyday forced to engage in simple repetitive operations on the assembly line, instead, on the one hand, it should make full use of modern scientific and technical knowledge to improve work efficiency, on the other hand, it also requires counselors themselves need to have a strong ability to learn and create knowledge. We can say that college counselors work is mainly a way of thinking activity, that is, those that are good at organizing, leading, handling complex systems including human problems. From a professional point of characteristics and occupational characteristics of counselors work, college counselors already have attributes of knowledge workers, belong to the category knowledge workers with a dual identity of university teachers and administrators. All levels of education authorities and universities must re-examine the fundamental value of counselors and fully affirm the value of human capital as a counselor team itself has knowledge workers, counselors recognize specialization, professionalization of the positive value and in practice to effectively promote the professionalization of counselors, professional building. It can choose a teacher or counselor individuals in management positions according to the actual situation, for the instructor choosing teacher positions should be included in the professional teachers titles in the series to protect them enjoy the same treatment as professional teachers in the work, research, training aspects; For the counselors selecting management positions, it needs to consider the differences between school counselors work with other administrative positions, and consider implementing counselors rank system construction, referring to teachers' professional titles series to set several levels of counselors, and the corresponding professional teachers rank corresponding appropriate professional and technical positions.

\section{B. Strengthen counselor service function to promote professionalism construction}

With the transformation of the main functions of our colleges and universities, from education managementoriented to education management, counselors also shift to the ideological and political education teacher from the beginning establishment of a political counselor, and their work is no longer confined to the framework of students' ideological and political education and include a variety of student affairs. Counselors should not only have the ideological and political education, higher education, psychology and other knowledge but also should have a lasting and stable career interests, strong professional pride, rich practical and innovative, high degree of professionalism and exemplary. Therefore, enhancing service awareness is apparent to promote the work develop toward the direction of professionalism.

\section{Scientifically to set counselor jobs to promote the development counselor work content}

Setting a quota and posts for counselors is human capital investment protection for counselors to promote standardization construction. There is not yet a unified standard how to set up the preparation and job counselors, and the practice practice is to determine the number of the preparation of counselors based on certain student ratio, to set the appropriate category counselor jobs in accordance with the needs of the time evolution of the ideological and political education and student development elements. 
According to the fundamental needs of college students and educational content development, the university should not only change the status counselor to student ratio is too high, at the same time, it should also cultivate high-quality talent away from higher education, makes the general "counselors job" subdivide into ideological and political education instructor, student affairs management counselor, student mental health counselor, student career guidance counselor, student organizations guidance counselor, school counselor, etc. Only in this way, the counselor can free from transactional, experience-based counselor, making them more practical and energy, to conduct systematic in-depth professionalism study on the various problems encountered in the process of student growth and success. Improve the quality and level counselors work to make counselors and finally embark professional development.

\section{CONCLUSION}

Solve the outstanding problems impeding the development of professionalism.First, change the concept and adjust the structure, in the introduction of counselors, it is necessary to consider political quality, comprehensive ability, work ethic, and it should also introduce teachers with psychology, education and professional background academic degree experience from serving the development needs of students; Second, define identity, for the flexibility provisions of counselors both teachers and cadres, it should further become college rigid regulations to ensure that counselors can choose teacher positions or cadre posts according to their actual and achieve their material and equal spiritual treatment just as professional teachers in the process of professional development; Third, standardize the work content to promote discipline construction work, and the work undertaken by counselors, such as caucus work, situation and policy education, employment guidance, student behavior guidance and mental health education should be incorporated into the school curriculum construction system, to promote counselors work move closer to subject of the construction, laying the foundation for professional counselors discipline development.

\section{References}

[1] Zhang Xiaoying, Zhong Jun, Ye Shaocan. The new college counselor professional development problems and countermeasures [J]. Ideological Education Research, 2011,07: 99-101.

[2] Zhou Qi. Review college counselors professional development [J]. School Party and ideological education (first half), 2008,08: 73-75.

[3] Chen Mingxia. Construction of political education and professional development of professional counselors thought [J]. Ideological Education Research, 2012,12: 95-98.

[4] Qiu Fengxing, Zhang Xiaoming. College counselors professional development bottleneck and breakthrough path [J]. College counselors, 2012,06: 76-79.

[5] Xie Junjun. The plight of the professional development of college counselors and responses [J]. Today China Forum, 2013,19: 88-89 + 91. 